Provided for non-commercial research and education use. Not for reproduction, distribution or commercial use.

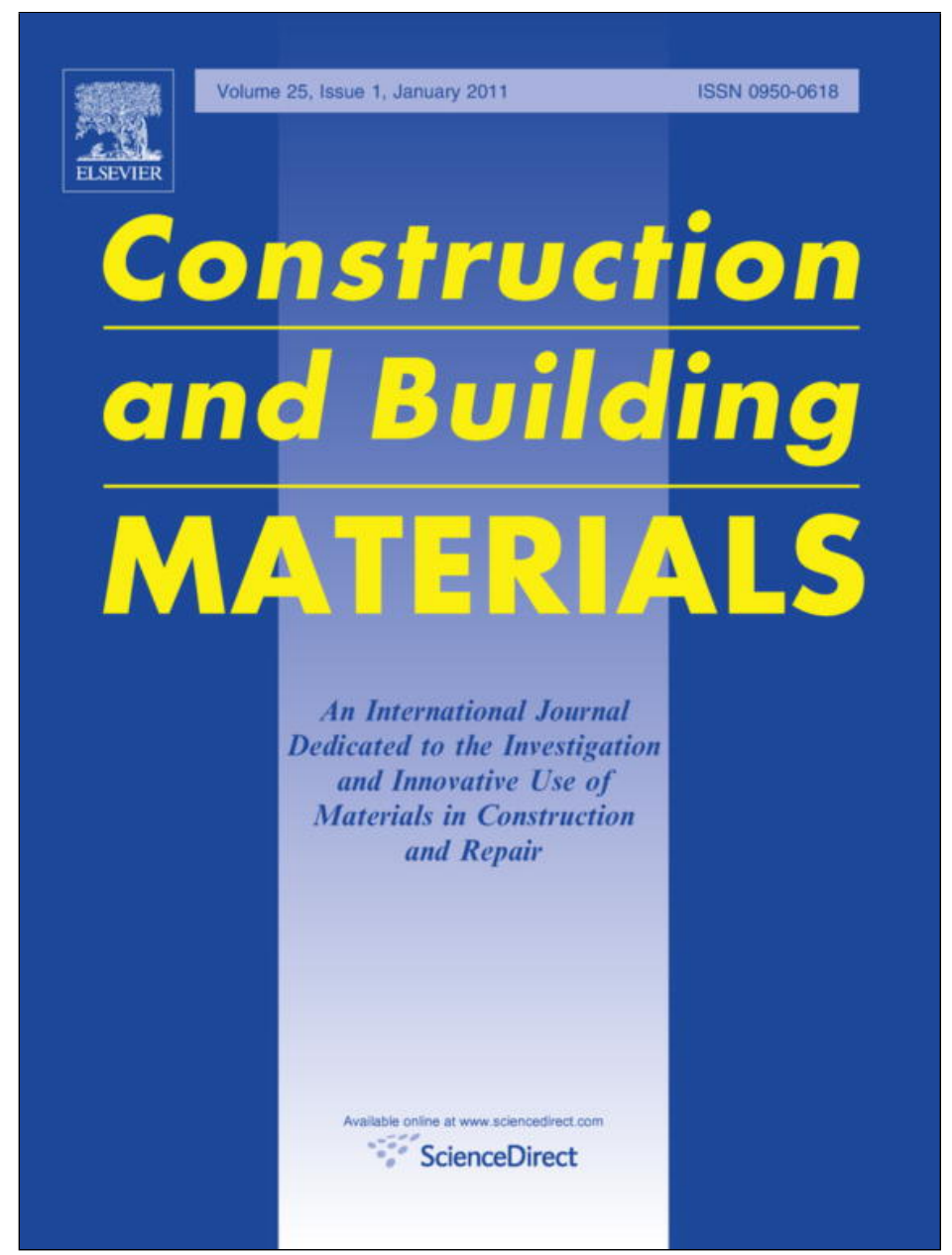

(This is a sample cover image for this issue. The actual cover is not yet available at this time.)

This article appeared in a journal published by Elsevier. The attached copy is furnished to the author for internal non-commercial research and education use, including for instruction at the authors institution and sharing with colleagues.

Other uses, including reproduction and distribution, or selling or licensing copies, or posting to personal, institutional or third party websites are prohibited.

In most cases authors are permitted to post their version of the article (e.g. in Word or Tex form) to their personal website or institutional repository. Authors requiring further information regarding Elsevier's archiving and manuscript policies are encouraged to visit:

http://www.elsevier.com/copyright 
Review

\title{
Properties and durability of concrete containing polymeric wastes (tyre rubber and polyethylene terephthalate bottles): An overview
}

\author{
F. Pacheco-Torgal ${ }^{\mathrm{a}, *}$, Yining Ding ${ }^{\mathrm{b}}$, Said Jalali ${ }^{\mathrm{a}}$ \\ ${ }^{a}$ University of Minho, C-TAC Research Centre, Guimarães, Portugal \\ ${ }^{\mathrm{b}}$ State Key Laboratory of Coastal and Offshore Engineering, Dalian University of Technology, Dalian, China
}

\section{A R T I C L E I N F O}

\section{Article history:}

Received 7 September 2010

Received in revised form 12 October 2011

Accepted 24 November 2011

Available online $\mathrm{xxxx}$

\section{Keywords:}

Polymeric wastes

Tyre rubber

Polyethylene terephthalate bottles

Concrete

Properties

Durability

\begin{abstract}
A B S T R A C T
The volume of polymeric wastes like tyre rubber and polyethylene terephthalate bottles (PET) is increasing at a fast rate. An estimated 1000 million tyres reach the end of their useful lives every year and 5000 millions more are expected to be discarded in a regular basis by the year 2030. Up to now a small part is recycled and millions of tyres are just stockpiled, landfilled or buried. As for PET bottles annual consumption represent more than 300,000 million units. The majority is just landfilled. This paper reviews research published on the performance of concrete containing tyre rubber and PET wastes. Furthermore it discusses the effect of waste treatments, the size of waste particles and the waste replacement volume on the fresh and hardened properties of concrete.
\end{abstract}

(c) 2011 Elsevier Ltd. All rights reserved.

\section{Contents}

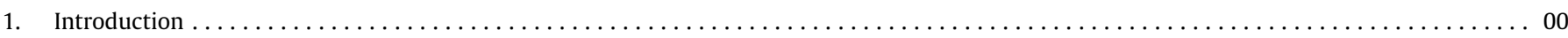

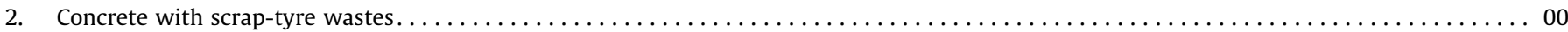

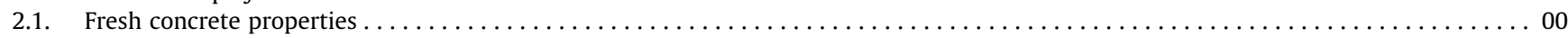

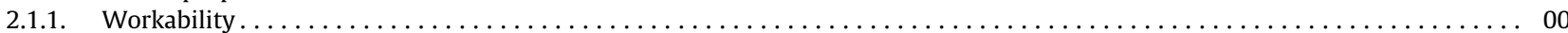

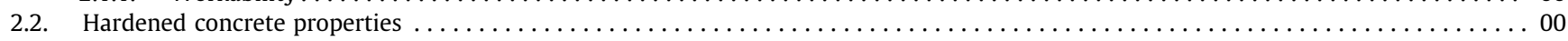

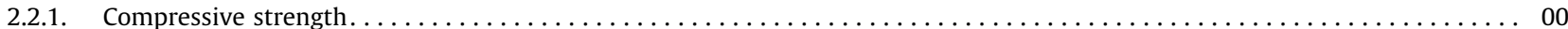

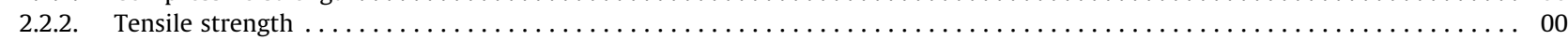

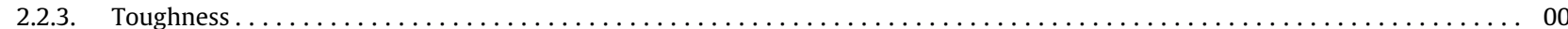

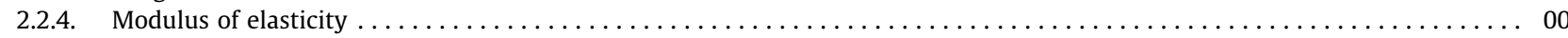

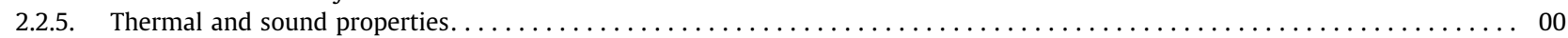

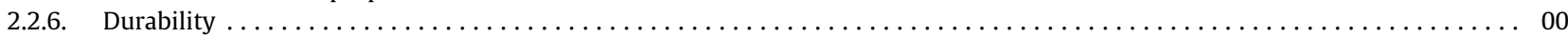

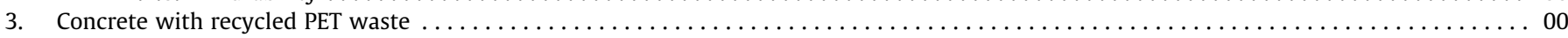

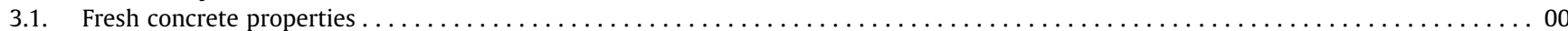

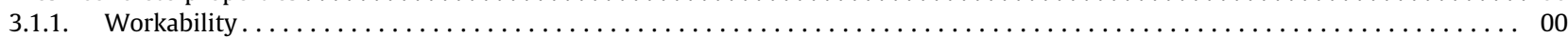

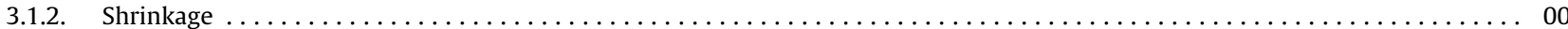

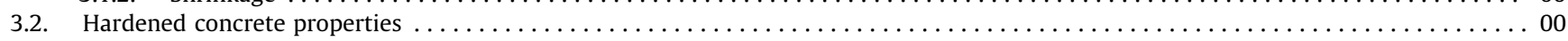

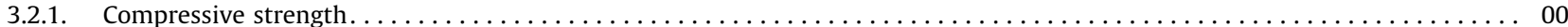

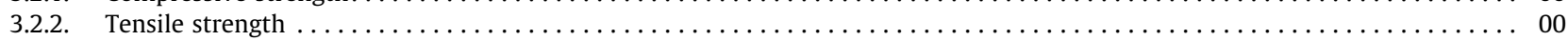

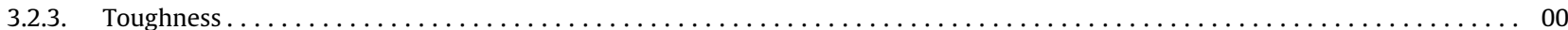

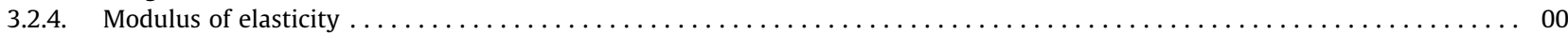

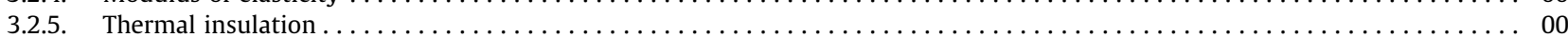

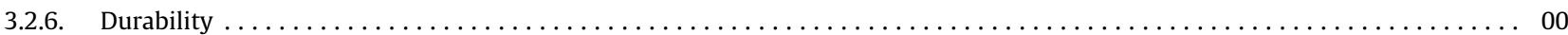

\footnotetext{
* Corresponding author. Address: University of Minho, C-TAC Research Centre 4800 Guimarães, Portugal. Tel.: +351 253 510200; fax: +351253510213.

E-mail address: torgal@civil.uminho.pt (F. Pacheco-Torgal).
} 


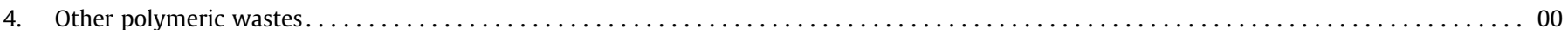

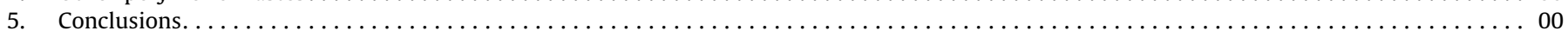

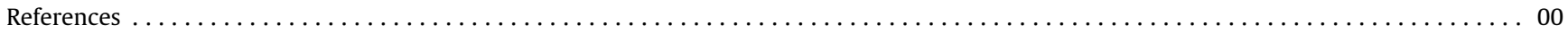

\section{Introduction}

Polymeric wastes namely tyre rubber and PET represents a major environmental problem of increasing relevance. An estimated 1000 million tyres reach the end of their useful lives every year [1]. At present enormous quantities of tyres are already stockpiled (whole tyre) or landfilled (shredded tyre), 3000 millions inside EU and 1000 millions in the US [2]. By the year 2030 the number of tyres from motor vehicles is expect to reach 1200 million representing almost 5000 millions tyres to be discarded in a regular basis. Tyre landfilling is responsible for a serious ecological threat. Mainly waste tyres disposal areas contribute to the reduction of biodiversity also the tyres hold toxic and soluble components [3]. Secondly although waste tyres are difficult to ignite this risk is always present. Once tyres start to burn down due to accidental causes high temperature take place and toxic fumes are generated [4] besides the high temperature causes tyres to melt, thus producing an oil that will contaminate soil and water. In Wales a tyre dump with 10 million tyres has been burning continuously for 9 years [5]. The implementation of the Lanfill Directive 1999/31/ EC [6] and the End of Life Vehicle Directive 2000/53/EC [7] banned the landfill disposal of waste tyres creating the driving force behind the recycling of these wastes. Still millions of tyres are just being buried all over the world [8]. Tyre rubber wastes are already used for paving purposes, however, it can only recycle a part of these wastes [9]. Another alternative are artificial reef formation but some investigation have already questioned the validity of this option [10]. Tyre waste can also be used in cement kilns for energetic purposes [11] and to produce carbon black by tyre pyrolisis [12], a thermal decomposition of these wastes in the absence of oxygen in order to produce by-products that have low economic viability. Some research has already been conducted on the used of waste tyre as aggregate replacement in concrete showing that a concrete with enhanced toughness and sound insulation properties can be achieved. Rubber aggregates are obtained from waste tyres using two different technologies: mechanical grinding at ambient temperature or cryogenic grinding at a temperature below the glass transition temperature [13]. The first method generates chipped rubber to replace coarse aggregates. As for the second method it usually produce crumb rubber [14] to replace fine aggregates. Since the cement market demand is expected to have a twofold increase (Fig. 1) this means that concrete volume is expect

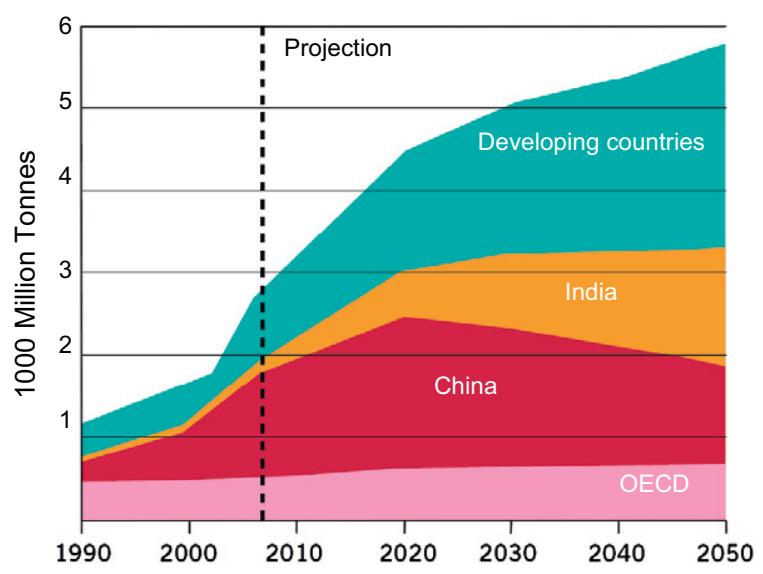

Fig. 1. Global cement demand by region and country [15]. to increase in a similar pattern representing an excellent way to reuse wastes like tyre rubber. Similar considerations can be made for PET wastes. This polymeric waste represents one of the most common plastics in solid urban waste [16]. In 2007 the world́s annual consumption represented 250,000 million terephthalate bottles (10 million tons of waste) with a growth increase of $15 \%$. In the United States 50,000 million bottles are landfilled each year [17]. Since PET waste is not biodegradable it can remain in nature for hundreds of years. Previous investigations already confirmed the potential of PET waste in replacing aggregates in concrete which represents a better option than landfill. In this work the most relevant knowledge about the properties and the durability of concrete containing polymeric wastes (tyre rubber and PET wastes) will be reviewed.

\section{Concrete with scrap-tyre wastes}

\subsection{Fresh concrete properties}

\subsubsection{Workability}

Cairns et al. [5] used long and angular coarse rubber aggregates with a maximum size of $20 \mathrm{~mm}$ obtaining concretes with an acceptable workability for low rubber content. These authors reported a reduction in the workability for higher rubber content, being that a rubber content of $50 \%$ lead to a zero slump value. Other authors [18] studied concretes containing silica fume, crumb rubber and tyre chips reporting a decrease in slump with increasing rubber content, being that a 50\% rubber content leads to mixtures without any workability. The results obtained by those authors show that reducing $\mathrm{W} / \mathrm{C}$ is associated to a decrease in the slump values and that the silica fume worsens the workability performance. Albano et al. [19] replace fine aggregates by $5 \%$ and $10 \%$ of scrap rubber waste (particle sizes of $0.29 \mathrm{~mm}$ and $0.59 \mathrm{~mm}$ ) reporting a decreased of $88 \%$ in concrete slump. Bignozzi and Sandrolini [20] used scrap-tyre $(0.5-2 \mathrm{~mm})$ and crumb-tyre $(0.05-0.7 \mathrm{~mm})$ to replace $22.2 \%$ and $33.3 \%$ of fine aggregates in self-compacting concretes referring that the introduction of the rubber particles does not influence the workability in a significant way if the superplasticizer also increases. Skripkiunas et al. [21] used crumbed rubber to replace $23 \mathrm{~kg}$ of fine aggregates in concretes with $0.6 \%$ of a policarboxile superplasticizer by cement mass obtaining the same workability of the reference concrete. Other authors [22] used crumb rubber tyres $(0.075-4.75 \mathrm{~mm})$ in the concrete to replace sand in various percentages $(20 \%, 40 \%, 60 \%$ and $100 \%)$. These authors stated that increasing rubber waste content decreases the concrete slump (Table 1). Freitas et al. [23] used scrap-tyre $(0.15-4.8 \mathrm{~mm})$ in the replacement of sand reporting a slump decrease along with the increase of scrap-tyre content. However, these authors used $1 \%$ by cement mass of an unknown plasticizer in the mixtures with tyre wastes, so the workability reduction is probably related to the low performance of the plasticizer. Topçu and Bilir [24] studied the influence of rubber waste with a maximum dimension of $4 \mathrm{~mm}$ in self-compacting concretes noticing that rubber replacing sand increase concrete workability which is due to the presence of viscosity agents even to a volume of $180 \mathrm{~kg} / \mathrm{m}^{3}$. Aiello and Leuzzi [25] used tyre shreds (Fig. 2) to replace fine and coarse aggregates ( $10 \mathrm{~mm}-25 \mathrm{~mm}$ ) with $1 \%$ by cement mass of a plasticizer observing increase workability with tyre shreds content (Table 2). Guneyisi [26] used crumb rubber waste to replace sand in self-compacting concretes in different 
Table 1

Slump performance according to crumb rubber content [22].

\begin{tabular}{cl}
\hline Rubber content $(\%)$ & Slump $(\mathrm{mm})$ \\
\hline 0 & 75 \\
20 & 61 \\
40 & 36 \\
60 & 18 \\
80 & 10 \\
100 & 5
\end{tabular}
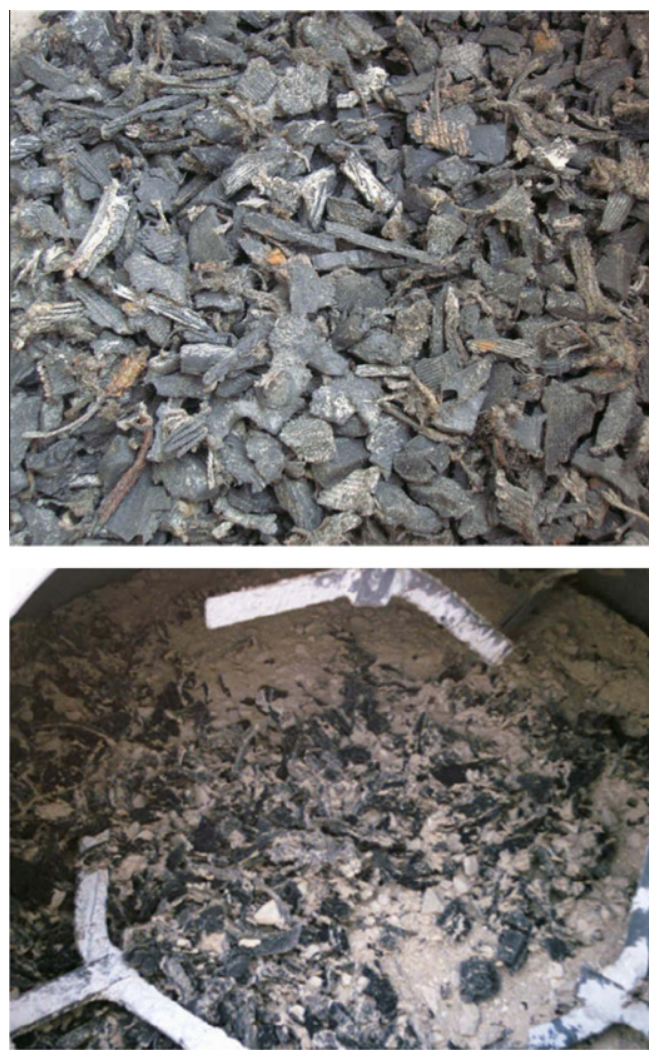

Fig. 2. Rubber particles: (above) as they come after the shredding process; (below) during the mixture of concrete [25].

percentages $(5,15$ and 25$)$ and using also a polycarboxylic superplasticizer with different amounts. This author noticed that the mixture with $25 \%$ of rubber waste although containing $4 \%$ by cement mass of the superplasticizer did not achieved the target slump flow of $750 \mathrm{~mm} \pm 50 \mathrm{~mm}$. He also reported that adding fly ash helps to lower the amount of superplasticizer in the mixtures with high rubber waste content. Although the majority of investigations show that rubber aggregates lead to a decrease in concrete workability some authors reported the no workability loss and others even observed the opposite behaviour this means that workability is very dependent on the characteristics of the rubber aggregates. Future investigations should study what rubber wastes could be used to produce self-compacting concretes.

\subsection{Hardened concrete properties}

\subsubsection{Compressive strength}

Guneyisi et al. [18] mentioned that the strength of concretes containing silica fume, crumb rubber and tyre chips decreases with rubber content. These authors suggest that it is possible to produce a $40 \mathrm{MPa}$ concrete replacing a volume of $15 \%$ of aggregates by rubber waste. Ghaly and Cahill [27] studied the use of different
Table 2

Slump tests of fresh concrete with aggregates replaced by rubber particles [25].

\begin{tabular}{ll}
\hline Mixture & Slump $(\mathrm{mm})$ \\
\hline Reference concrete with rubber waste & 180 \\
$\quad$ replacing coarse aggregates $(\mathrm{W} / \mathrm{B}=0.52)$ & \\
25\% Rubber vol. & 220 \\
50\% Rubber vol. & 215 \\
75\% Rubber vol. & 215 \\
Reference concrete with rubber waste & 180 \\
replacing fine aggregates (W/B = 0.60) & \\
15\% Rubber vol. & 220 \\
30\% Rubber vol. & 220 \\
50\% Rubber vol. & 215 \\
75\% Rubber vol. & 225 \\
\hline
\end{tabular}

percentage of rubber in concrete $(5 \%, 10 \%$, and $15 \%$ ) by volume also noticing that as rubber content increase leads to a reduction of compressive strength. Valadares [28] studied the performance of concretes with the same volume replacement of rubber wastes confirming the decrease of compressive strength. A waste rubber volume of $15 \%$ leads to a $50 \%$ compressive strength decrease. These authors mentioned that the rubber waste with low dimensions leads to lower strength loss and also that the rubber production (mechanical grinding or cryogenic process) does not influence the compressive strength. Freitas el al. [23] mentioned a 48.3\% decrease in compressive strength for concretes with a waste rubber volume of $15 \%$. Ganjian et al. [29] also confirmed the decrease in compressive strength for increase rubber content. However, these authors obtained a slight increase in compressive strength when $5 \%$ of chipped rubber replaced the coarse aggregates probably due to a better grading of the mixture. This finding had already caught the attention of other authors [30,31]. Snelson et al. [32] used concretes with shredded tyre chips $(15-20 \mathrm{~mm})$ for aggregate replacement in several percentages $(2.5 \%, 5 \%$ and $10 \%)$ reporting a loss in compressive strength. The results show that the rubber mixtures also containing pulverised fuel ash as partial cement replacement presented major compressive strength loss. This means that the low adhesion between the cement paste and the rubber waste becomes even lower if admixtures with low pozzolanic activity are used. Aiello and Leuzzi [25] used tyre shreds to replace fine and coarse aggregates concluding that the size of the rubber particles have a major influence on the compressive strength. When coarse aggregates are replaced by the tyre particles the compressive strength loss is much more profound when compared to the compressive strength loss of concretes in which fine aggregates were replaced by rubber particles (Table 3 ). These results contradict the ones presented by Valadares [28] and that may be related to the origin of the wastes used in each case (car, truck or motorcycle) being that different origin may possess different chemical compositions leading to different adhesion between the cement paste and the rubber waste. Vieira et al. [9] studied three types of rubber waste (Fig. 3) and three volume percentages (2.5\%; $5 \%$ and $7.5 \%$ ) reporting that the best mechanical performance was obtained using just $2.5 \%$ of the tyre rubber with $2.4 \mathrm{~mm}$. Several authors mentioned the use of pretreatments of rubber waste to increase the adhesion between the cement paste such as the use of a $10 \%$ $\mathrm{NaOH}$ saturated solution to wash the rubber surface during 20 min [33,34]. Raghavan et al. [35] confirms that the immersion of rubber in $\mathrm{NaOH}$ aqueous solution could improve the adhesion leading to a high strength performance of concrete rubber composites. The $\mathrm{NaOH}$ removes zinc stearate from the rubber surface, an additive responsible for the poor adhesion characteristics, enhancing the surface homogeneity [36]. Segre and Joekes [37] mention several pretreatments to improve that the adhesion of rubber particles like acid etching, plasma and the use of coupling agents. Cairns et al. [5] used rubber aggregates coated with a thin layer of cement paste (Fig. 4). Albano et al. [19] study concrete 
Table 3

Compressive strength of concrete with aggregates replaced by rubber particles [25].

\begin{tabular}{lll}
\hline Mixture & Compressive strength (MPa) & Compressive strength decrease (\%) \\
\hline Reference concrete with rubber waste replacing coarse aggregates (W/B = 0.52) & 45.8 & - \\
25\% Rubber vol. & 23.9 & 47.8 \\
50\% Rubber vol. & 17.4 & 54.4 \\
75\% Rubber vol. & 27.1 & 61.9 \\
Reference concrete with rubber waste replacing fine aggregates (W/B = 0.60) & 24.0 & - \\
15\% Rubber vol. & 20.4 & 11.6 \\
30\% Rubber vol. & 19.5 & 24.7 \\
50\% Rubber vol. & 17.1 & 28.3 \\
\hline
\end{tabular}

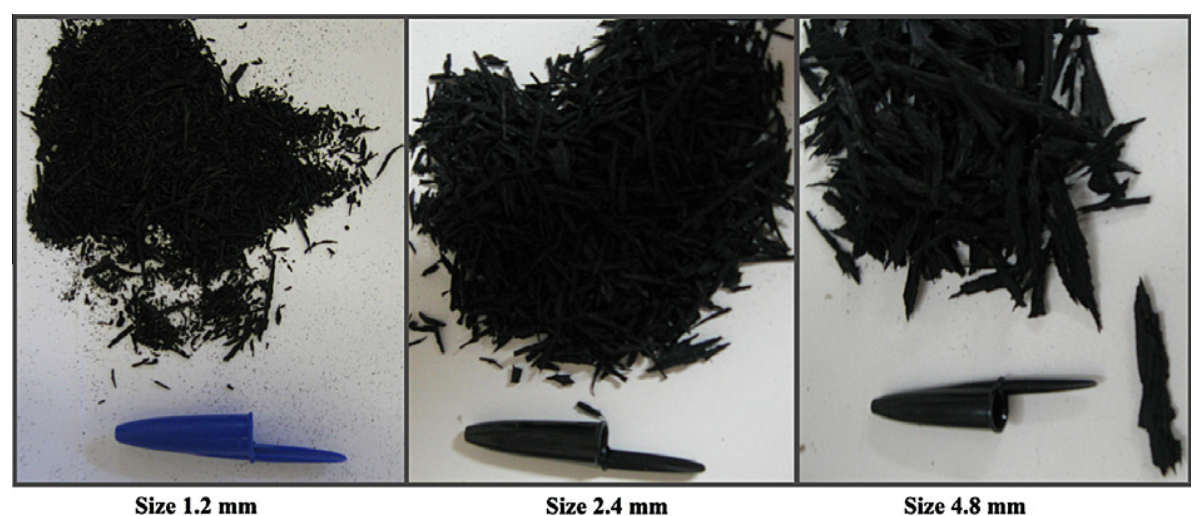

Fig. 3. Size of tire rubber [9].
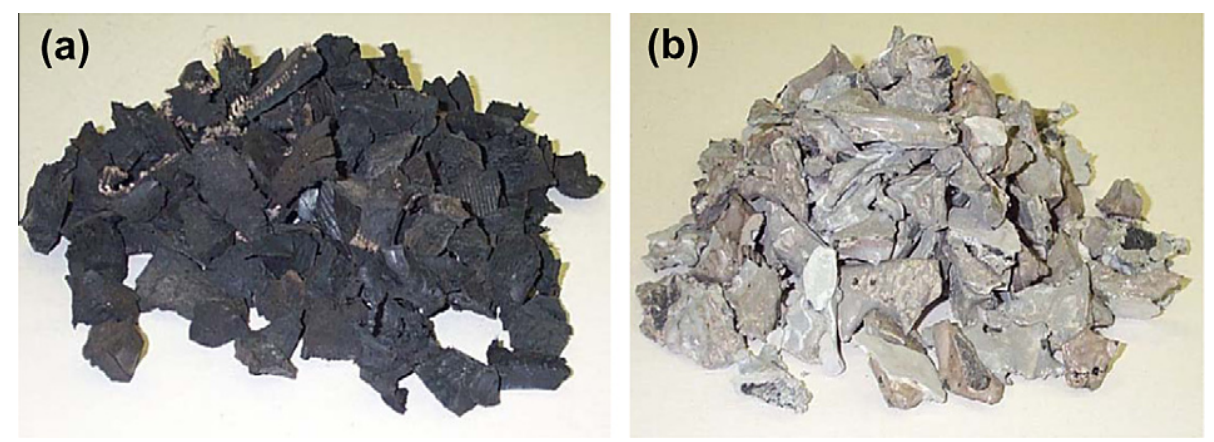

Fig. 4. A $20 \mathrm{~mm}$ rubber aggregate particles: (a) plain; (b) coated with cement paste [5].

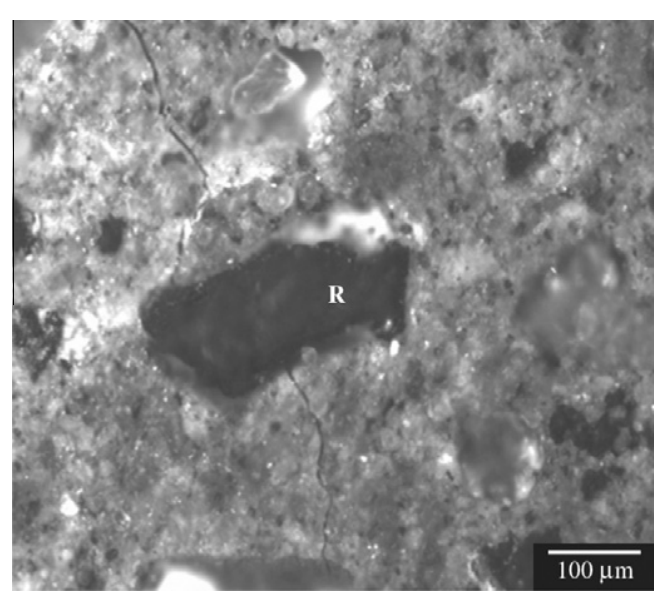

Fig. 5. Cracking bridging effect of rubber particles [41]. composites containing scrap rubber previously treated with $\mathrm{NaOH}$ and silane in order to enhance the adhesion between the rubber and the cement paste without noticing significant changes, when compared to the untreated rubber composites. Oiknomou et al. [38] mentioned that the use of SBR latex enhances the adherence between the rubber waste and the cement paste. Chou et al. [39] suggest the pretreatment of crumb rubber with organic sulphur stating it can modify the rubber surface properties increasing the adhesion between the waste and the cement paste. Investigations about rubber waste concrete show a compressive strength loss with waste content increase. This behaviour is related to the low compressive strength of rubber aggregates and to the low adhesion between these wastes and the cement paste. Several treatments reveal interesting results in order to overcome this disadvantage. Further investigations are needed on this subject, especially to comprehend if different kinds of rubber behave in a similar manner to the same treatment. 
Table 4

Tensile strength (flexural) of concrete with aggregates replaced by rubber particles [25].

\begin{tabular}{ll}
\hline Mixture & Tensile strength (MPa) \\
\hline Reference concrete with rubber waste replacing coarse aggregates (W/B = 0.52) & 3.51 \\
25\% Rubber vol. & 2.93 \\
$50 \%$ Rubber vol. & 2.52 \\
75\% Rubber vol. & 2.52 \\
Reference concrete with rubber waste replacing fine aggregates (W/B = 0.60) & 5.34 \\
15\% Rubber vol. & 5.10 \\
$50 \%$ Rubber vol. & 5.03 \\
$75 \%$ Rubber vol. & 4.95 \\
\hline
\end{tabular}
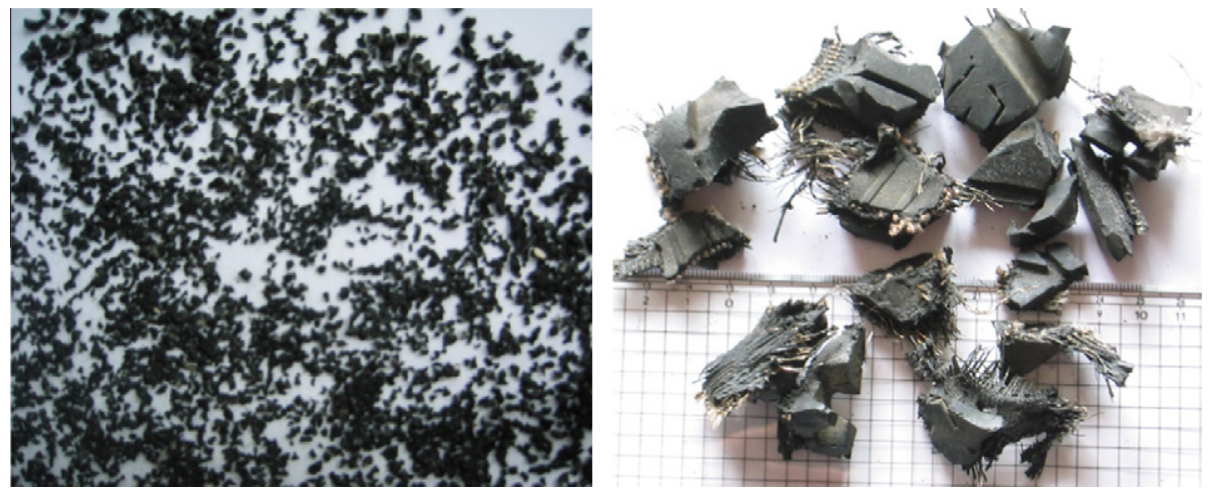

Fig. 6. Tyre rubber waste: left - ground; rigth - crushed [45].

\subsubsection{Tensile strength}

Guneyisi et al. [18] analyzed the tensile strength of concretes containing silica fume, crumb rubber and tyre chips referring a decrease in tensile strength according to the rubber content also that the presence of silica fume is beneficial because it is responsible for a higher filler effect. The results also confirm that the decrease of tensile strength reduction is less influenced by the rubber content than for the compressive strength reduction. This tendency was also observed by Pierce and Williams [40]. This result appears to be due to the fact that rubber particles prevent crack opening (Fig. 5). Valadares [28] obtained a higher tensile strength for concretes with rubber waste particles with a higher dimension which agrees with the previous finding. Ganjian et al. [29] mentioned the opposite behaviour reporting that the tensile strength of concrete with chipped rubber replacement for aggregates is considerably lower than for concrete containing powdered rubber. In the first case a reduction between $30 \%$ and $60 \%$ takes place for a replacement level of $5-10 \%$, as for the latter case the reduction is between $15 \%$ and $30 \%$. This behaviour maybe related to the very low adhesion between the chipped rubber and the cement paste. One reason for this is the fact that chipped rubber was prepared in laboratory with the help of a scissor a procedure quite different from the rubber waste particles shredded by a grinding process which favors a harsh surface. According to Aiello and Leuzzi [25] when tyre shreds are used to replace fine aggregates a high tensile (flexural) strength is obtained. A replacement of the volume of fine aggregates (50\% or $75 \%$ ) leads to a strength reduction of only $5.8 \%$ and $7.30 \%$. But if the same percentages were used to replace coarse aggregates a $28.2 \%$ strength reduction will take place (Table 4). The tensile strength of rubber waste concrete is influenced by the characteristics of the rubber aggregate. Some are associated with a tensile strength loss but others present a high tensile strength. Future investigation should focus on the characteristics of the rubber aggregates that enhance tensile strength.

\subsubsection{Toughness}

Concrete composites containing tyre rubber waste are known for their high toughness [42], having a high energy absorption capacity. The ASTMC1018-97 [43] defines several toughness indexes ( $I_{5}, I_{10}$ and $\mathrm{I}_{20}$ ) as the area under load-deflection curve of a flexural specimen for different times of deflection after crack initiation related to area under the same curve up to the crack initiation. Some authors [44] report a $63.2 \%$ increase in the damping ratio (self capacity to decrease the amplitude of free vibrations) for concrete containing $20 \%$ rubber particles. Other authors $[45,46]$ confirmed the high damping potential of rubber waste concrete. They mentioned that concrete with ground rubber shows a $75.3 \%$ increase in the damping ratio and a $144 \%$ for crushed rubber concrete (Fig. 6). Fioriti et al. [47] mentioned that concrete paving blocks containing $8 \%$ of tyre rubber waste (have a resistant impact of almost 300\% when compared to the reference concrete. Ling et al. [48] also studied the performance of concrete paving blocks with crumb rubber reporting a high toughness resistance due to the energy absorbing capacity. These means that tyre waste concrete maybe specially recommended for concrete structures located in areas of severe earthquake risk and also for the production of railway sleepers.

\subsubsection{Modulus of elasticity}

Since the concrete with rubber waste has low compressive strength and a correlation exists between compressive strength and the modulus of elasticity it is expected they also possess lower modulus of elasticity. However, Skripkiunas et al. [21] compared concretes with similar compressive strength (a reference one and another with $3.3 \%$ of crumb rubber) obtaining different static modulus of elasticity, 29.6 GPa versus $33.2 \mathrm{GPa}$ for the reference concrete just $11 \%$ higher. The explanation for this behaviour is related to the low modulus of elasticity of rubber waste [49]. Other authors [50] report a decrease in the modulus of elasticity of $40 \%$ when the same percentage reduction takes place for compressive 
Table 5

Modulus of elasticity according to rubber content [52].

\begin{tabular}{cll}
\hline $\begin{array}{l}\text { Rubber content } \\
(\%)\end{array}$ & $\begin{array}{l}\text { Compressive strength } \\
(\mathrm{MPa})\end{array}$ & $\begin{array}{l}\text { Modulus of } \\
\text { elasticity (GPa) }\end{array}$ \\
\hline 0 & 43 & 35 \\
10 & 30 & 23 \\
15 & 20 & 19 \\
20 & 15 & 15 \\
25 & 12 & 10 \\
\hline
\end{tabular}

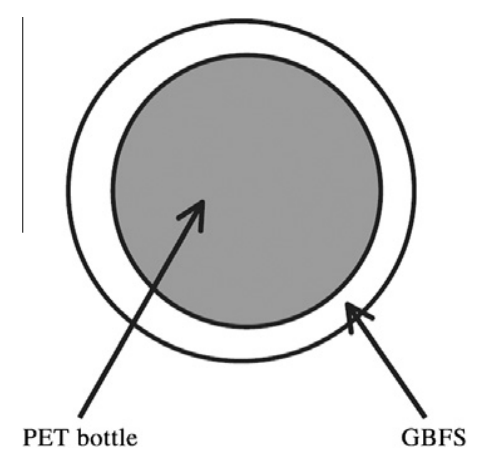

Fig. 7. PET waste/GBFS aggregates [60].

strength. Khaloo et al. [51] confirmed that the inclusion of tyre rubber particles leads to a high ductility concrete. Zheng et al. [45,46] mentioned that the crumb rubber $(80 \%<2.62 \mathrm{~mm})$ has a lower influence in the modulus of elasticity than the crushed rubber $(15-40 \mathrm{~mm})$. Turatsinze and Garros [52] refer that the modulus of elasticity of self-compacting concrete is increased with rubber (4-10 mm) waste content (Table 5). These authors also mentioned the risk of severe segregation with a high concentration of rubber waste at the top of the specimens which implies the needed for a proper combination between a viscosity agent and air-entraining agent to avoid segregation. Other authors [53] studied the modulus of elasticity of concrete columns with two different sizes of crumb rubber $(0.6$ and $1 \mathrm{~mm})$ reporting an increase in the ductility performance up to $90 \%$. Those authors mentioned that crumb rubber concrete columns can undergo twice the lateral deformation before failure compared to the reference concrete columns. Mohammed [54] confirmed that concrete slabs containing crumb rubber with a finesses modulus of 2.36 shows a higher ductility behaviour which fulfil the ductility requirements of Eurocode 4 [55].

\subsubsection{Thermal and sound properties}

The replacement of fine aggregates by crumb rubber lowers the thermal conductivity of concrete [56]. The replacement of up to $30 \%$ reduces the thermal conductivity by more than $50 \%$ to a minimum of $0.241 \mathrm{~W} / \mathrm{m} \mathrm{K}$. Crumb rubber concrete also show high noise reduction behaviour for high-frequency ranges (higher than $1000 \mathrm{~Hz}$ ) when compared to the reference concrete. Crumb rubber concrete shows a noise reduction coefficient $36 \%$ higher. This reveals an ideal application for noise reduction barriers. However, further investigations are still needed regarding the aggregate characteristics and concrete mixes that could enhance sound proof performance and at the same time can keep a minimum compressive strength and durability.

\subsubsection{Durability}

Since rubber waste concrete has lower compressive strength and lower tensile strength than reference concrete it is expected that is behaviour under fast mechanical degradation actions could also be lower. Sukontasukkul and Chaikaew [57] mentioned that
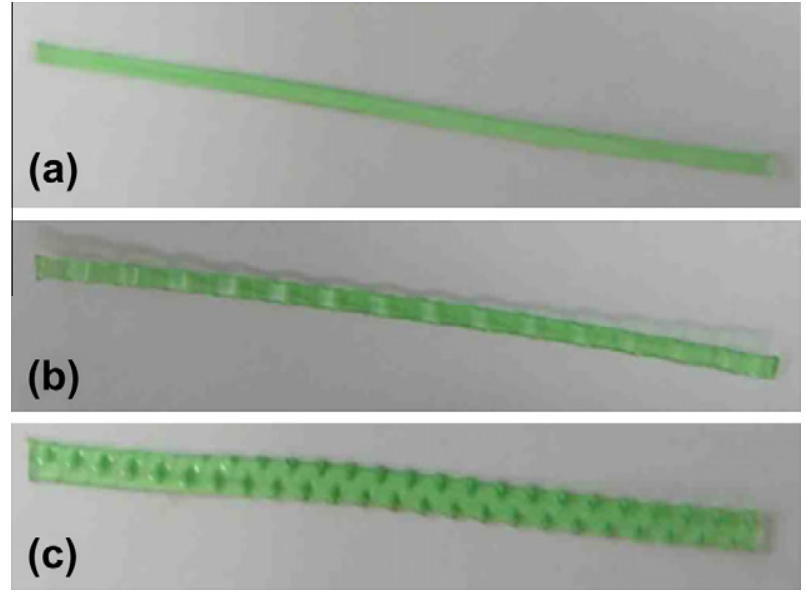

Fig. 8. Geometry of recycled $50 \mathrm{~mm}$ long PET fibres: (a) straight type (cross section $0.5 \times 1 \mathrm{~mm}$ ); (b) crimped type (cross section $0.3 \times 1.2 \mathrm{~mm}$ ); (c) embossed type (cross section $0.2 \times 1.3 \mathrm{~mm}$ ) [62].

crumb concrete blocks show less abrasion resistance and also that increasing the crumb rubber content leads to a reduction in the abrasion resistance. This result is confirmed by other authors [48]. Freitas e al. [23] studied the abrasion resistance by immersion of rubber waste concrete reporting a lower degradation than the reference concrete when only $5 \%$ rubber per mass is used to replace the coarse aggregate. This result is quite interesting since the rubber addition leads to a $30 \%$ compressive strength decrease. However, since the tensile strength (Brazilian test) has been reduced only $11 \%$ this helps to understand the high abrasion resistance. The authors used this mixture in the rehabilitation of a hydroelectric power plant. Topçu and Demir [58] mentioned that a high volume replacement of sand by rubber waste $(1-4 \mathrm{~mm})$ has lower durability performance assessed by freeze-thaw exposure, seawater immersion and high temperature cycles. According to them the use of a $10 \%$ replacement is feasible for regions without harsh environmental conditions. The fact that these authors used a Portland cement II/B 32.5 which has a very low compressive strength one may be able to explain these results. Ganjian et al. [29] studied the durability of concrete containing scrap-tyre wastes assessed by water absorption and water permeability revealing that a percentage replacement of just $5 \%$ is associated with a more permeable concrete ( $36 \%$ increase) but not a more porous one. Increasing the rubber percentage replacement to $10 \%$ doubles the concrete water permeability which means this kind of concrete cannot be used for applications where water pressure is present like underwater columns. Ling et al. [59] tested 348 rubber waste paving blocks reporting that an increase in the rubber waste decreases the abrasion resistance. Thus the recommendation that a 20 vol.\% replacement should not be exceeded. The durability of rubber waste concrete is a subject that needs further investigations. How different wastes influence durability parameters and most importantly how waste treatment can enhance the concrete durability are questions that must be addressed.

\section{Concrete with recycled PET waste}

\subsection{Fresh concrete properties}

\subsubsection{Workability}

Choi et al. [60] mentioned that increasing PET waste aggregates leads to an increase in the workability. This result is related to the spherical and smooth shape of the aggregates used in the investigation which are made of PET waste and ground granulated blast 
furnace slag (GBFS). According to these authors these are aggregates are made inside a mixer with a inner temperature of $250 \pm 10^{\circ} \mathrm{C}$. At this temperature the PET particles start to melt down and then they mix with the GBFS particles resulting in a composite aggregate with a PET core and a GBFS surface (Fig. 7). Batayneh et al. [61] reported a decrease of slump with increasing PET waste for aggregate replacement. Being that a $20 \%$ replacement leads to a decrease of slump by $20 \%$ to $58 \mathrm{~mm}$. The workability of PET concrete is influenced by the fact that PET wastes were previously submitted to a treatment. It remains to be seen if these treatments have an environmental impact that shadow's the ecological benefits of using PET wastes.

\subsubsection{Shrinkage}

Kim et al. [62] studied the influence of three types of PET based fibres (Fig. 8) on the control of plastic shrinkage. These fibres are obtained from melted PET waste to form a roll-type sheet. Then the sheet is cut into $0.5 \mathrm{~mm}$ long fibres and a deforming machine is used to change the fibre surface geometry. They mentioned that the use of a volume of just $0.25 \%$ PET fibres can reduce the plastic shrinkage, increasing PET fibres volume beyond $0.25 \%$ does very little to the shrinkage reduction. The results confirmed that the embossed type fibre, the one that has the best mechanical resistance leads to the best shrinkage performance. Kim et al. [63] confirm the concrete crack control ability of PET fibre composites. These authors compared the shrinkage performance of embossed type PET fibre previously submitted to a surface treatment to improve dispersion and bonding strength [64] to the shrinkage performance of crimped polypropylene commercial fibres (PP) reporting a slightly better behaviour for composites containing $0.5 \%$ of PP fibres. Nevertheless, composites containing $1 \%$ of PET fibres have a quite similar performance. Since investigations on concrete shrinkage performance used treated PET fibres investigations should study which treatment is the one with the lowest environmental impact.

\subsection{Hardened concrete properties}

\subsubsection{Compressive strength}

Some authors suggest that PET waste can be used to produce an unsaturated polyester resin in the presence of glycols and dibasic acid. This material would serve as binder to produce polymer concrete with high mechanical performance [65-69]. Jo et al. [70] confirm the high compressive strength of PET waste polymer concrete. The same authors [71] also found out that this type of concrete can also be used to incorporate recycled concrete aggregates with minor strength loss. Mahdi et al. [72] also investigate the use of PET waste to produce a polyester resin referring that the use of PET to glycol ratio of 2:1 has a positive effect on the compressive strength of polymer concrete. However, polymer concrete presents a significant strength decrease with increasing temperature. Rebeiz [73] mentioned that polymer concrete can loose almost $45 \%$ of compressive strength for a temperature exposure of $60^{\circ} \mathrm{C}$. Choi et al. [60] mentioned that the replacement of fine aggregates for PET/GBFS aggregates $(5-15 \mathrm{~mm}$ ) leads to a decrease in the compressive strength. For a $25 \%$ replacement the mixtures with a $\mathrm{W} / \mathrm{C}=0.45$ and 3 curing days lost just $6.4 \%$ in compressive strength. For 28 curing days the

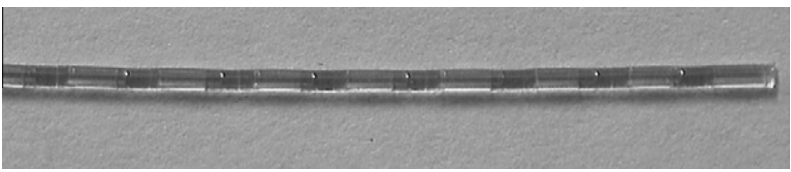

Fig. 9. Indented PET fibre [75]
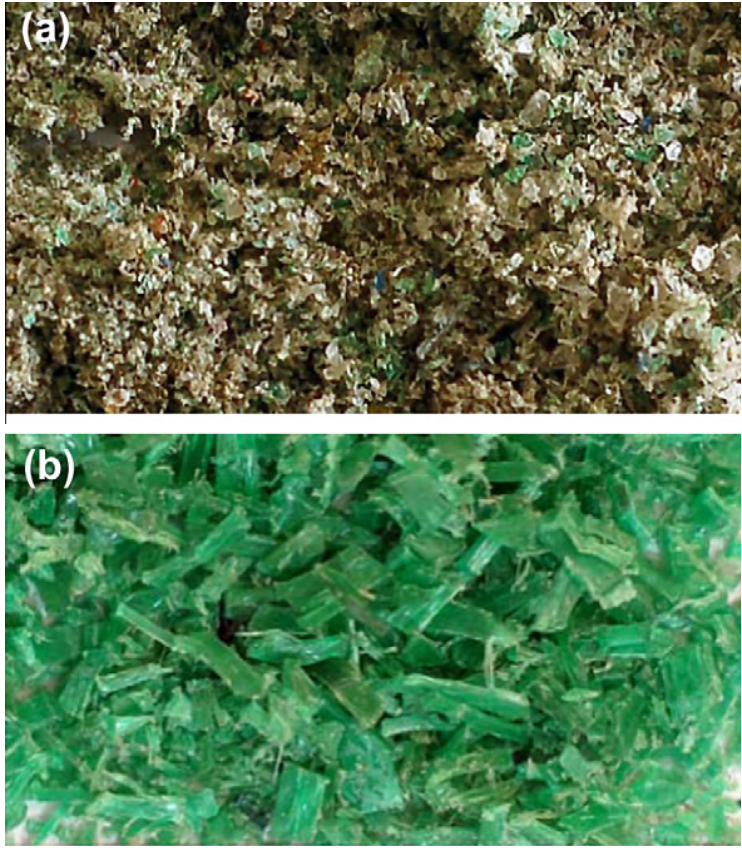

Fig. 10. PET waste types: (a) sand type; (b) flake type [76].

compressive strength loss reaches just 9.1\%. Increasing the replacement percentage increases compressive strength loss but not in a proportional manner, for instance a $75 \%$ replacement the mixtures with a $\mathrm{W} / \mathrm{B}=0.45$ and 3 curing days lost just $16.5 \%$ in compressive strength. This means that these treated PET aggregates perform in almost a similar way as natural aggregates. Other authors [61] mentioned a severe compressive strength decrease of $72 \%$ for just $20 \%$ volume replacement of untreated PET waste. This behaviour is very different of the one reported by previous authors which means that using untreated PET waste implies the use of a very small volume in order to obtain an acceptable compressive strength concrete. Marzouk et al. [74] also studied the influence of crushed PET waste reporting compressive strength decrease with increase replacement volume as long as the maximum dimension of the aggregates are
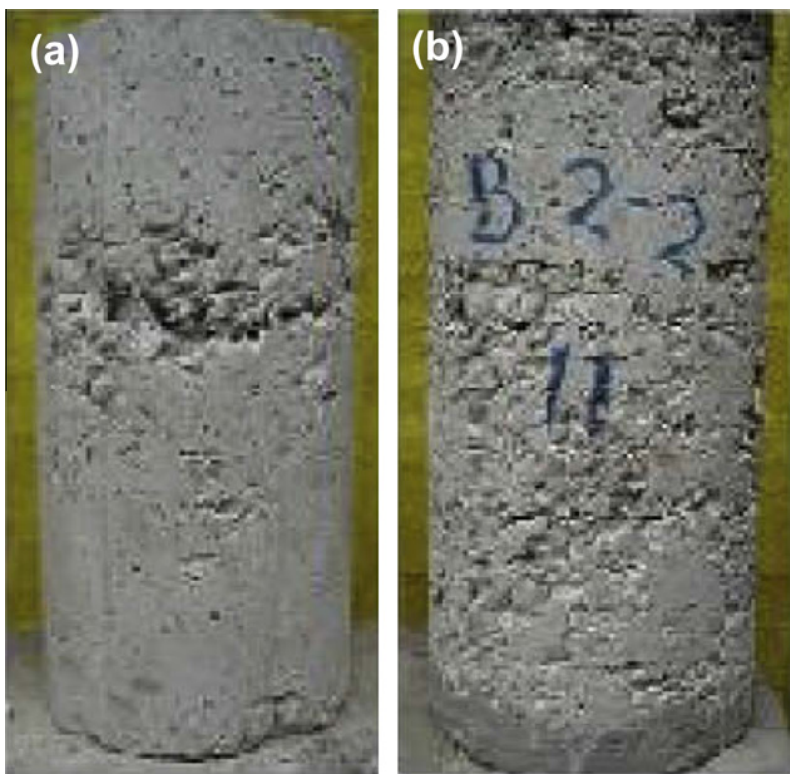

Fig. 11. Concrete specimens with honeycombs: (a) partial; (b) total [77]. 
below $2 \mathrm{~mm}$. For plastic particles with a maximum dimension of $5 \mathrm{~mm}$ the compressive strength remains almost unchanged up to a volume replacement of $40 \%$. Ochi et al. [75] mentioned that concrete mixtures with a low percentage of indented PET waste fibres obtained through a melting process (Fig. 9) have an acceptable mechanical performance. A mixture with 1.5 vol.\% replacement show a minor compressive strength loss of $3.6 \%$ for a $\mathrm{W} / \mathrm{B}=0.55$. These authors mentioned that these fibres are already used in Japan at least since 2004 for tunnel support and also that they are as costly as steel fibres. Modro et al. [76] studied the influence of two types of PET waste (Fig. 10) on the compressive strength of concrete composites. The results are different according to the PET type. The concrete with sand PET presents a severe compressive strength loss with increasing waste content. As to the mixtures with the flake PET the strength loss is always less pronounced and in some conditions (replacement volume up to $10 \%$ ) the strength loss is not relevant. According to these authors the strength loss is related to the porosity of the concrete specimens but also to the compressive strength of the PET waste. Albano et al. [77] studied concrete mixtures with two PET waste replacement percentages (10\% and $20 \%$ ) and with different PET dimensions ( $2.6 \mathrm{~mm}, 11.4 \mathrm{~mm}$ and a mix of the two). The results show that concretes with a waste content of $20 \%$ and a higher waste dimensions ( $11.4 \mathrm{~mm}$ ) have a higher compressive strength loss above $60 \%$. Using just $10 \%$ PET waste replacement with a mix of the dimensions $2.6 \mathrm{~mm}$ and $11.4 \mathrm{~mm}$ (in equal parts) showed slight reductions in the strength loss between $15 \%$ and $20 \%$. These authors also report that mixtures with high dimension waste particles and a 20\% waste volume should be avoided because they present formation of honeycombs (Fig. 11). Other authors [78] reported compressive strength losses of $6 \%, 16 \%$ and $30 \%$ for waste replacement percentages of $15 \%, 50 \%$ and $75 \%$, referring that behaviour is independent of the $\mathrm{W} / \mathrm{C}$ ratio. Such high mechanical performance can be explained by the treatment to which the PET waste was submitted (Fig. 12). Akcaozoglu et al. [79] mentioned a slight reduction in compressive strength from $31.1 \mathrm{MPa}$ to $28.8 \mathrm{MPa}$ for 180 curing days specimens when the PET waste increase from $50 \%$ to $100 \%$ in mixtures of cement/ GBFS (50\%/50\%). Frigione [80] report that the replacement of $5 \%$ PET waste $(0.1-5 \mathrm{~mm})$ by natural aggregates leads to irrelevant compressive strength loss (0.4-1.9\%) in specimens with 1 year curing. Other authors [63] report a irrelevant compressive strength loss for concretes with up to $1 \%$ embossed PET fibres waste. Hannawi et al. [81] studied the performance of cementitious composites containing PET and polycarbonate wastes (Fig. 13) reporting a similar compressive strength behaviour for both

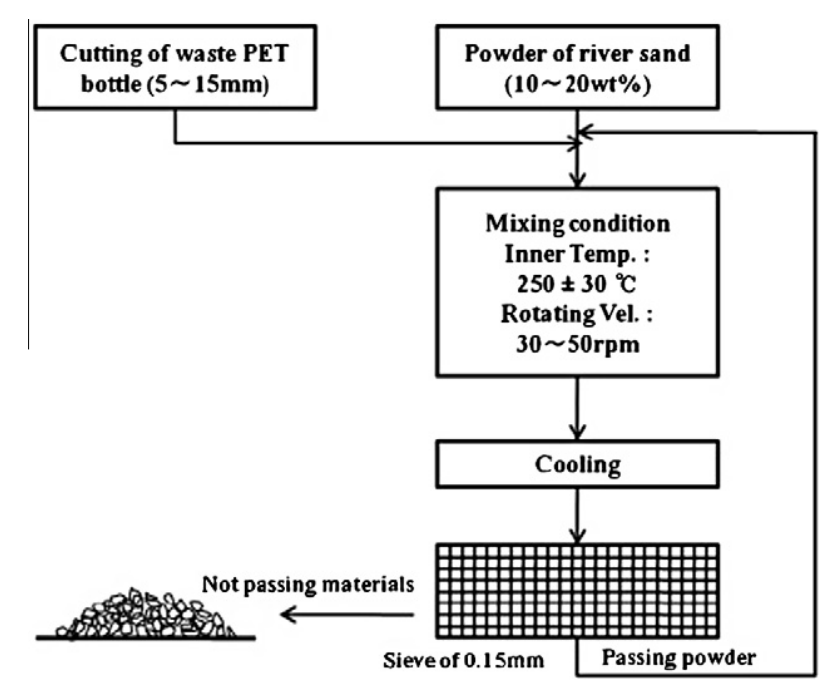

Fig. 12. PET waste/sand production [78]. wastes revealing a serious strength loss with increasing waste content.

\subsubsection{Tensile strength}

Jo et al. [70] mentioned that polymer concrete made with unsaturated polyester resin form PET waste can achieve a very high tensile strength (22.4 MPa in flexural and 7.85 in splitting test). For the replacement of fine aggregates for PET/GBFS aggregates Choi et al. [60] mentioned a decrease in the splitting tensile strength of $16 \%$ for a $25 \%$ replacement volume. Since the loss percentage is quite higher than for the compressive strength of the same mixture probably this would mean that the artificial PET aggregates have a low adhesion to the cement paste. Ochi et al. [75] mentioned that the use of treated $30 \mathrm{~mm}$ long of indented PET fibres can lead to a tensile strength increase for volume replacements up to $1.5 \%$. Marzouk et al. [74] found that the tensile strength and the compressive strength of crushed PET concrete composites have a similar loss pattern. For Albano et al. [77] the tensile strength loss is dependent on the volume of PET waste as to the PET particles dimensions, being that the mixtures with the smallest ones present lower tensile strength. Other authors [78] reported that the ratio flexural-tensile strength/compressive strength of PET waste mixtures is similar to that of current cementitious composites. Frigione [80] mentioned that cementitious composites containing PET and polycarbonate wastes have similar tensile flexural strength performance. These authors also mentioned that a volume replacement up $20 \%$ does not generate a relevant tensile strength loss. And that an increase in the replacement volume from $20 \%$ to $50 \%$ leads to a $36 \%$ tensile strength loss for polycarbonate mixtures while the same replacement volume with PET waste is responsible for a tensile strength loss of $11 \%$.

\subsubsection{Toughness}

Silva et al. [82] mentioned that recycled monofilament PET fibres increases the toughness indexes of cementitious composites. Also Hannawi et al. [81] mentioned that PET and polycarbonate wastes composites have a high energy absorbing behaviour even with a high waste content. Other authors [63] used embossed type PET fibre reporting that fibre concrete allows a mid-span deflection that is 4 times higher when compared to free fibre concrete. Still investigations that clarify which is the treatment with the lowest environmental impact that maximizes the toughness characteristics of PET concrete are need.

\subsubsection{Modulus of elasticity}

Marzouk [74] report that the modulus of elasticity of PET based composites decrease slightly with increasing waste content up to $20 \%$ (just 5\%). Beyond this level the modulus of elasticity presents a severe decrease with waste content. A $40 \%$ replacement volume leads to a decrease in the modulus of elasticity of $21.4 \%$. Results also show that mixtures with small PET particles have lower modulus of elasticity. Kim et al. [63] confirmed the reduction in the elasticity modulus with increasing embossed PET waste fibres. However, since these authors used replacement volumes up just to $1.0 \%$ they report irrelevant changes. The same happen with crimped polypropylene fibres based mixtures For steel reinforced concrete beams these authors mentioned that using $0.5 \%$ embossed PET fibres leads to maximum ductility. That makes it 10 times higher when compared to concrete beams without fibres.

\subsubsection{Thermal insulation}

Marzouk et al. [83] mentioned that a 50 vol.\% replacement of fine aggregates by PET wastes leads to a reduction of the thermal conductivity by $46 \%$ from $1.28(\mathrm{~W} / \mathrm{m} \mathrm{K})$ to $0.69(\mathrm{~W} / \mathrm{m} \mathrm{K})$. Yesilata et al. [84] obtained a $10 \%$ reduction in the thermal insulation of concrete specimens with square PET particles with a volume of 

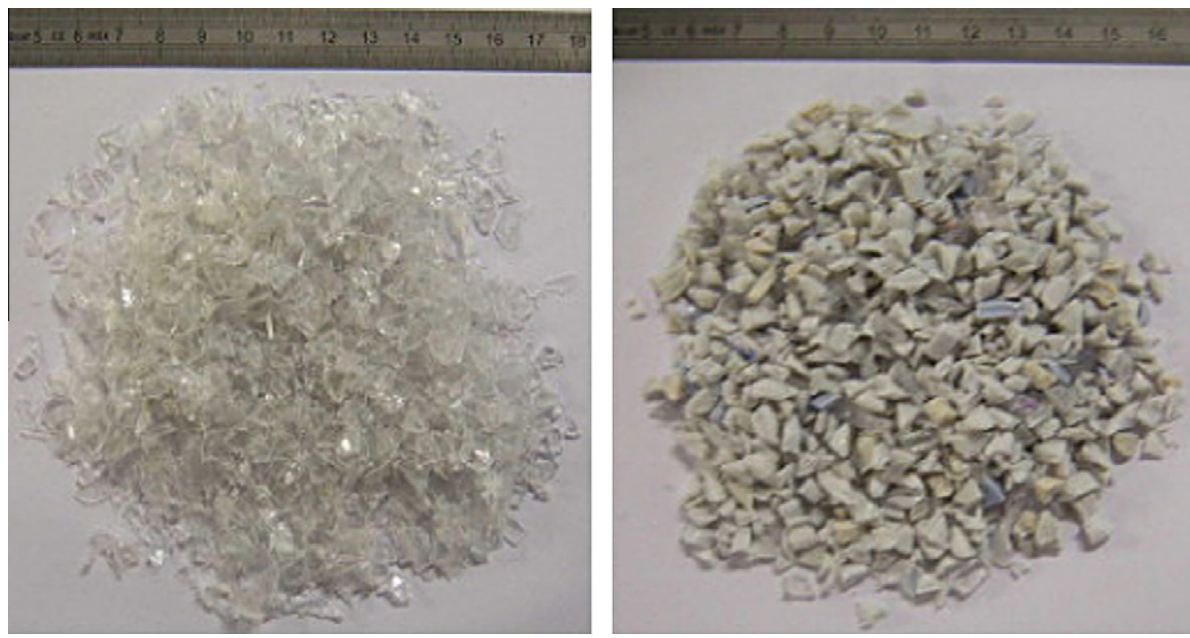

Fig. 13. Polymeric wastes: (left) PET-aggregates; (right) polycarbonate-aggregates [81].

$0.9 \%$ related to the volume of the concrete specimens. The results also show that when strip or irregular PET particles are used the thermal insulation of the specimens increase from $10 \%$ to $17 \%$. The results show that square type PET particles have low adhesion to cement past resulting in a composite with high thermal conductivity. PET concrete composites show an interesting thermal insulation performance. However, a high PET waste volume is needed to insure a low thermal conductivity coefficient and that will imply a high mechanical strength loss.

\subsubsection{Durability}

Silva et al. [82] mentioned that, with time, PET fibres degrade in the alkaline environment of the cement paste. The mechanism of PET degradation involves a depolymerization reaction that breaks the polymer chain splitting it in two groups (the aromatical ring and the aliphatic ester). Infrared spectrum of PET fibre after immersion in alkaline solutions that reproduces the alkaline conditions of pore solution show the presence of bands assigned to the aromatic ring. As a result of PET fibre degradation the toughness performance of cementitious composites decreases with time. These authors mentioned a 20\% loss between specimens with 42 curing days and 104 curing days. Ochi et al. [75] mentioned that treated indented PET fibres show high resistance chemical degradation in an alkaline medium. These authors compared the alkali resistance of treated PET fibres with the resistance of PP and PVA fibres reporting that the former retains $99 \%$ of their tensile strength while PP only retains $86 \%$ and PVA shows a severe degradation retaining only $56 \%$ of its tensile strength. Other authors [85] report that the partial replacement of cement by PET wastes contributes to the reduction of the chloride ion diffusion coefficient. Won et al. [86] studied the durability of embossed PET fibres composites. Although the results of chloride permeability are similar to the control concrete and freeze-thaw resistance is better than the control concrete the results related to exposure to an alkaline environment and to sulphuric acid reveal a performance that is not acceptable when it comes to real applications. Galvão et al. [87] compared the performance of PET based concrete composites versus the performance of concrete with low-density polyethylene fibres and tyre waste fibres. The results show that PET composites have the highest compressive strength with almost $30 \mathrm{MPa}$ for the worst case scenario (7.5\% volume replacement). Even for the tensile strength PET composites outperform the other wastes. As to the erosion-abrasion under water test the best results were obtained for mixtures with 5\% PET and 5\% low-density polyethylene fibres. When compared to the reference concrete erosion-abrasion resistance the $5 \%$ PET mixture presented less $23 \%$ of mass loss and
$5 \%$ low-density polyethylene fibres mixture presented less $40 \%$ of mass loss.

\section{Other polymeric wastes}

Several other polymeric wastes have been investigated about their potential to be used as aggregate replacement in cementitious composites. Laukaitis et al. [88] studied the development of lightweight thermo-insulating cementitious composites containing crumbled polystyrene waste and spherical blown polystyrene waste. The authors report the need to use a $0.2 \%$ sulfonyl and $0.03 \%$ glue hydro solution to increase the adhesion between the polystyrene granules and the cement paste. The results show that it is possible to produce a composite with $150-170 \mathrm{~kg} / \mathrm{m}^{3}$ and a thermal conductivity of coefficient between 0.06 and $0.0 .64 \mathrm{~W} /$ $\mathrm{m} \mathrm{K}$. Ismail et al. [89] mentioned that the use of polymeric wastes composed by $80 \%$ of polyethylene and $20 \%$ polystyrene as fine aggregate replacement increases the toughness of concrete with minor compressive and tensile strength decrease. However, the same authors report workability issues that need to be addressed. For instance mixtures with a $15 \%$ replacement volume have an almost null slump. Other authors [90] studied concretes with ground thermosetting polymer (melamine) waste reporting a reduction in compressive strength with waste content increase related to the poor adhesion between waste plastic and cement paste. Yadav [91] also confirms the strength reduction associated with concrete polymeric waste composites. Nevertheless, the results show that in spite of compressive strength reduction it is possible to produce non-loading-bearing lightweight concrete. Dweik et al. [92] also used concrete with a thermosetting polymer (ground melamineformaldehyde) waste as sand replacement. The authors mentioned a strength (both compressive and tensile) increase with waste content increase and also an increase in the thermal insulation. Mounanga et al. [93] mentioned that concrete composites containing polyurethane wastes from insulation panels although they have low thermal conductivity they present high compressive strength loss which is due to the weak and porous polyurethane aggregates. Results also show an increase in high drying shrinkage with increasing polymeric waste content. Fraj et al. [94] also studied polyurethane wastes based concrete reporting that waste replacement is responsible for a high compressive strength reduction. According to these authors the use of pre-soaked wastes together with a high $\mathrm{W} / \mathrm{C}>0.5$ was responsible for the high porosity explaining the compressive strength reduction. They suggest that using a lower $\mathrm{W} / \mathrm{C}$ ratio can increase the mechanical performance. Since the present conditions also led to a high drying shrinkage and an increase in 

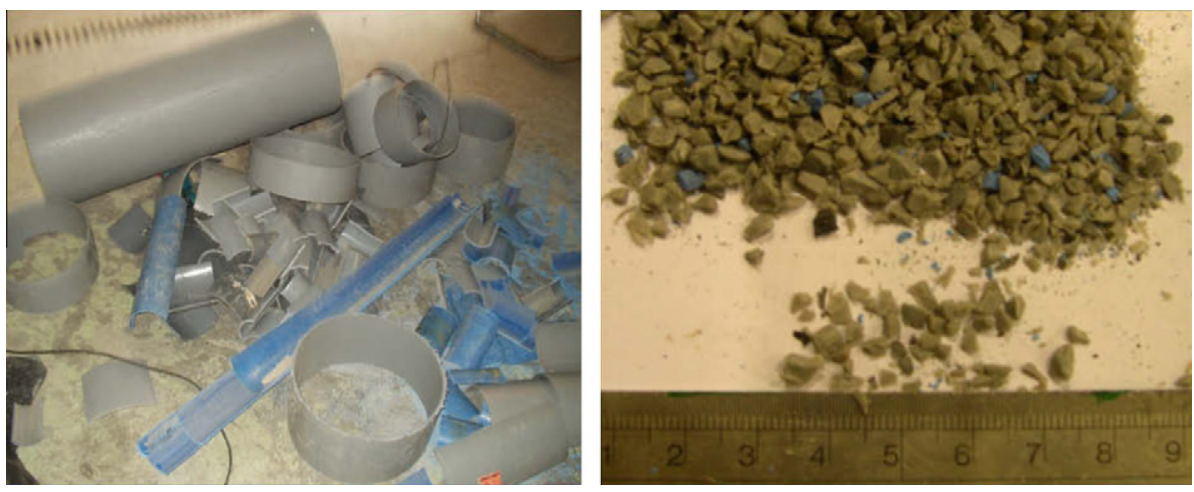

Fig. 14. PVC waste: (left) before crushing; (right) after crushing [95].

both gas permeability and chloride diffusion using a lower $\mathrm{W} / \mathrm{C}$ will probably improved the durability of these composites. Other authors [95] used minor amounts (up to 3\%) of low-density polyethylene fibres reporting the improvement of the toughness characteristics of concrete composites up to 7 times. Kou et al. [96] studied the influence of crush PVC wastes (Fig. 14) on the properties of concrete composites reporting a relevant compressive strength decrease with the increase in waste content. Since PVC aggregates have a compressive strength of $65 \mathrm{MPa}$ the compressive strength reduction of the concrete mixtures must be related to a low adhesion between PVC and the cement paste. The PVC aggregates also contribute to the reduction of the modulus of elasticity because of the low modulus of PVC. The results shows that concrete with increase PVC volume have a drying shrinkage decrease. For instance the use of just $15 \%$ PVC aggregates leads to a $50 \%$ reduction in the drying shrinkage. Studies about the durability of other polymeric wastes are scarce but some authors already report that the polyester and acrylic fibres can suffer from chemical degradation when immersed in the alkaline environment of a cement paste [97-99].

\section{Conclusions}

Tyre rubber and PET wastes represent a serious environmental issue that needs to be addressed with urgency by the scientific community. Investigations carried out so far reveal that tyre waste concrete is specially recommended for concrete structures located in areas of severe earthquake risk and also for applications submitted to severe dynamic actions like railway sleepers. This material can also be used for non-load-bearing purposes such as noise reduction barriers. Investigations about rubber waste concrete show that concrete performance is very dependent on the waste aggregates. Further investigations are needed to clarify for instance which are the characteristics that maximize concrete performance. As to PET based concrete the investigations show that this material is very dependent on the treatment of these wastes. At present PET fibres are already used to replace steel fibres and some authors even report the use of PET concrete mixtures for repairing concrete structures submitted to high underwater erosion. Nevertheless, future investigations should clarify which treatments can maximize concrete performance being responsible for the lowest environmental impact. Further investigations should also be carried on about the use of other polymeric wastes in concrete.

\section{References}

[1] World Bussiness Council for Sustainable Development - WBCSD. End-of-life tyres: a framework for effective management systems; 2010.

[2] Oikonomou N, Mavridou S. The use of waste tyre rubber in civil engineering works. In: Khatib J. editor. Sustainability of construction materials, ISBN 978-1-84569349-7. Abington Hall, Cambridge, UK: WoodHead Publishing Limited; 2009.
[3] Day K, Holtze K, Metcalfe J, Bishop C, Dutka B. Toxicity of leachate from automobile tyres to aquatic biota. Chemosphere 1993;27:665-75.

[4] Chen S, Su H, Chang J, Lee W, Huang K, Hsieh L, et al. Emissions of polycyclic aromatic hydrocarbons (PAHs) from the pyrolysis of scrap tyres. Atmosferic Environ 2007;41:1209-20.

[5] Cairns R, Kew H, Kenny M. The use of recycled rubber tyres in concrete construction. Final Report. The Onyx Environmental Trust, University of Strathclyde, Glasgow; 2004.

[6] European Commission. Council directive 1999/31/EC of 26 April 1999 on the landfill of waste. Official Journal of the European Communities, L182; 1999. p. 1-19.

[7] European Commission. Directive 2000/76/EC of the European Parliament and of the Council of 4 December 2000 on incineration of waste. Official Journal of the European Communities, L332; 2000. p. 91-111.

[8] http://www.pyreco.com/.

[9] Vieira R, Soares R, Pinheiro S, Paiva O, Eleutério J, Vasconcelos R. Completely random experimental design with mixture and process variables for optimization of rubberized concrete. Constr Build Mater 2010.

[10] Hartwell S, Jordahl D, Dawson C, Ives A. Toxicity of scrap tyre leachates in estuarine salinities: are tyres acceptable for artificial reefs? Trans Am Fish Soc 1998;127:796-806.

[11] Siddique R, Naik T. Properies of concrete containing scrap-tyre rubber - an overview. Waste Manage 2004;24:563-9.

[12] Farcasiu M. Another use for old tyres. Chem Tech 1993:22-4.

[13] Nagdi K. Rubber as an engineering material: guidelines for user. Hanser Publication; 1993.

[14] Eleazer, W., Barlaz, M., Whittle, D. Resource recovery alternatives for waste tires in North Carolina. School of Engineering, Civil Engineering Department, NCSU, US; 1992.

[15] Taylor M, Gielen D. Energy efficiency and $\mathrm{CO}_{2}$ emissions from the global cement industry. Int Energy Agency 2006.

[16] Mello D, Pezzin S, Amico S. The effect of post consumer PET particles on the performance of flexible polyurethane foams. Polym Test 2009;28:702-8.

[17] Gore A. Our choice. A plan to solve the climatic crisis. ISBN 978-989-8025-937, Esfera do Caos Editores; 2009.

[18] Guneyisi E, Gesoglu M, Ozturan T. Properties of rubberized concretes containing silica fume. J Cem Concr Res 2004;34:2309-17.

[19] Albano C, Camacho N, Reyes J, Feliu J, Hernández M. Influence of scrap rubber addition to Portland concrete composites: destructive and non-destructive testing. Compos Struct 2005;71:439-46.

[20] Bignozzi M, Sandrolini F. Tyre rubber waste recycling in self-compacting concrete. Cem Concr Res 2006;36:735-9.

[21] Skripkiunas G, Grinys A, Cernius B. Deformation properties of concrete with rubber waste additives. Mater Sci 2007;13:219-23.

[22] Batayneh M, Marie I, Asi I. Promoting the use of crumb rubber concrete in developing countries. J Waste Manage 2008;28:2171-6.

[23] Freitas C, Galvão J, Portella K, Joukoski A, Filho C. Desempenho fisico-químico e mecânico de concreto de cimento Portland com borracha de estirenobutadieno reciclada de pneus. Química Nova 2009;32:913-8.

[24] Topçu I, Bilir T. Experimental investigation of some fresh and hardened properties of rubberized self-compacting concrete. Mater Des 2009;30:3056-65.

[25] Aiello M, Leuzzi F. Waste tyre rubberized concrete: properties at fresh and hardened state. Waste Manage 2010;30:1696-704.

[26] Guneyisi E. Fresh properties of self-compacting rubberized concrete incorporated with fly ash. Mater Struct 2010.

[27] Ghaly A, Cahill J. Correlation of strength, rubber content, and water to cement ratio in rubberized concrete. Can J Civil Eng 2005;32:1075-81.

[28] Valadares F. Mechanical performance of structural concretes containing rubber waste from waste tires. Master Dissertation in Civil Engineering, ISTUTL, Lisbon; 2009 [only in Portuguese].

[29] Ganjian E, Khorami M, Maghsoudi A. Scrap-tyre-rubber replacement for aggregate and filler in concrete. Constr Build Mater 2009;23:1828-36.

[30] Biel T, Lee H. Magnesium oxychloride cement concrete with recycled tire rubber. Transportation Research Board, Report No 1561. Washington, DC: Transportation Research Board; 1996. p. 6-12. 
[31] Khatib Z, Bayomy F. Rubberized Portland cement concrete. ASCE J Mater Civ Eng 1999;11:206-13.

[32] Snelson D, Kinuthia JM, Davies P, Chang S. Sustainable construction: composite use of tyres and ash in concrete. Waste Manage 2009;29:360-7.

[33] Naik T, Singh S. Utilization of discarded tyres as construction materials for transportation facilities. Report No CBU - 1991-02, UWM Center for byproducts utilization. University of Wiscosin, Milwaukee; 1991. p. 16

[34] Naik T, Singh S, Wendorf R. Applications of scrap tire rubber in asphaltic materials: state of the art assessment. Report No CBU-1995-02, UWM Cente for by-products utilization. University of Wiscosin, Milwaukee; 1995. p. 49.

[35] Raghavan D, Huynh H. Ferraris C. Workability, mechanical properties, an chemical stability of a recycled tyre rubber filled cementitious composite. J Mater Sci 1998;33:1745-52.

[36] Segre N, Monteiro P, Sposito G. Surface characterization of recycled tire rubber to be used in cement paste matrix. J Colloid Interf Sci 2002;248:521-3.

[37] Segre N, Joekes I. Use of tire rubber particles as addition to cement paste. Cem Concr Res 2000;30:1421-5.

[38] Oiknomou N, Stefanidou M, Mavridou S. Improvement of the bonding between rubber tire particles and cement paste in cement products. In: $15^{\text {th }}$ Conference of the technical chamber of Greece, Alexandroupoli, Greece; 2006. p. 234-42.

[39] Chou L, Lin C, Lu C, Lee C, Lee M. Improving rubber concrete by waste organic sulfur compounds. Waste Manage Res 2010;28:29-35.

[40] Pierce C, Williams R. Scrap tire rubber modified concrete: Past, present and future. In: Limbachiya M, Roberts J. editors. Proceedings of the internationa conference organized by the concrete and masonry research group. Sustainable Waste Management and Recycling: Used - Post-Consumer Tires, Thomas Telford; 2004. p. 1-16.

[41] Segre N, Ostertag C, Monteiro P. Effect of tire rubber particles on crack propagation in cement paste. Mater Res 2006;9:311-20.

[42] Li G, Garrick G, Eggers J, Abadie C, Stubblefield M, Pang S. Waste tire fiber modified concrete. Composites: Part B 2004;35:305-12.

[43] ASTM C1018-97. Standard test method for flexural toughness and first-crack strength of fibre-reinforced concrete. Pennsylvania; 1997.

[44] Balaha M, Badawy A, Hashish M. Effect of using ground waste tire rubber as fine aggregate on the behaviour of concrete mixes. Indian J Eng Mater Sci 2007;14:427-35.

[45] Zheng L, Huo S, Yuan Y. Experimental investigation on dynamic properties of rubberized concrete. Constr Build Mater 2008;22:939-47.

[46] Zheng L, Huo X, Yuan Y. Strength, modulus of elasticity, and brittleness index of rubberized concrete. J Mater Civ Eng 2008;20:692-9.

[47] Fioriti C, Ino A, Akasaki J. Concrete paving blocks with tyre wastes. Revista Internacional Construlink 2007;15(5):56-67 [only in Portuguese].

[48] Ling T, Nor H, Hainin M, Chik A. Laboratory performance of crumb rubber concrete block pavement. Int J Pavement Eng 2009;10:361-74.

[49] Anison M. An investigation into a hypothetical deformation and failure mechanism for concrete. Mag Concr Res 1964;47:73-82.

[50] Turatsinze A, Bonnet S, Granju J. Potential of rubber aggregates to modify properties of cement based-mortars: improvement in cracking shrinkage resistance. Constr Build Mater 2007;21:176-81.

[51] Khaloo A, Dehestani M, Rahmatabadi P. Mechanical properties of concrete containing a high volume of tire-rubber particles. Waste Manage 2008;28:2472-82.

[52] Turatsinze A, Garros M. On the modulus of elasticity and strain capacity of selfcompacting concrete incorporating rubber aggregates. Resour Conserv Recycl 2008;52:1209-15.

[53] Son K, Hajirasouliha I, Pilakoutas K. Strength and deformability of waste tyre rubber-filled reinforced concrete columns. Construction and Building Materials 2011:25:218-26.

[54] Mohammed BS. Structural behavior and m-k value of composite slab utilizing concrete containing crumb rubber. Constr Build Mater 2010;24:1214-21.

[55] EN1994 - Eurocode 4. Design of composite steel and concrete structure. British Standards Institution London; 1994

[56] Sukontasukkul P. Use of crumb rubber to improve thermal and sound properties of pré-cast concrete panel. Constr Build Mater 2009;23:1084-92.

[57] Sukontasukkul P, Chaikaew C. Properties of concrete pedestrian block mixed with crumb rubber. Constr Build Mater 2006;20:450-7.

[58] Topçu I, Demir A. Durability of rubberized mortar and concrete. J Mater Civ Eng 2007;19:173-8.

[59] Ling T, Nor H, Lim S. Using recycled waste tyres in concrete paving blocks. Proc Inst Civ Eng: Waste Resour Manage 2010;163:37-45.

[60] Choi Y, Moon D, Chung J, Cho S. Effects of waste PET bottles aggregate on the properties of concrete. Cem Concr Res 2005;35:776-81.

[61] Batayneh M, Marie I, Asi I. Use of selected waste materials in concrete mixes. Waste Manage 2007;27:1870-6

[62] Kim J, Park C, Lee S, Lee S, Won J. Effects of the geometry of recycled PET fibre reinforcement on shrinkage cracking of cement-based composites. Composites: Part B 2008;39:442-50.

[63] Kim S, Yi N, Kim H, Kim J, Song Y. Material and structural performance evaluation of recycled PET fiber reinforced concrete. Cem Concr Compos 2010;32:232-40

[64] Won J, Park C, Kim H, Lee S. Effect of hydrophilic treatments of recycled PET fibre on the control of plastic shrinkage cracking of cement-based composites. J Korean Soc Civ Eng 2007;27:413-9.

[65] Rebeiz K, Fowler D, Paul D. Mechanical properties of polymer concrete systems made with recycled plastic. ACI Mater J 1994;91:40-5.
[66] Rebeiz K, Serhal S, Fowler D. Structural behaviour of polymer concrete beams using recycled plastics. ASCE J Mater Civ Eng 1994;6:150-65.

[67] Rebeiz K. Precast use of polymer concrete using unsaturated polyester resin based on recycled PET waste. Constr Build Mater 1994;10:215-20.

[68] Rebeiz K, Yang S, David W. Polymer mortar composites made with recycled plastics. ACI Mater J 1994;91:313-9.

[69] Rebeiz K, Fowler D. Flexural strength of reinforced polymer concrete made with recycled plastic waste. ACI Struct J 1996;93:524-30.

[70] Jo B, Seung-Kook P, Cheol-Hwan K. Mechanical properties of polyester polymer concrete using recycled polyethylene terephthalate. ACI Struct J 2006;103:219-25.

[71] Jo B, Park S, Park J. Mechanical properties of polymer concrete made with recycled PET and recycled concrete aggregates. Constr Build Mater 2008;22:2281-91.

[72] Mahdi F, Abbas H, Khan A. Strength characteristics of polymer mortar and concrete using different compositions of resins derived from post-consumer PET bottles. Constr Build Mater 2010;24:25-36.

[73] Rebeiz K. Time temperature properties of polymer concrete using recycled PET. Cem Concr Compos 1995;17:119-24.

[74] Marzouk O, Dheilly R, Queneudec M. Valorization of post-consumer waste plastic in cementitious concrete composites. Waste Manage 2007;27:310-8.

[75] Ochi T, Okubo S, Fukui K. Development of recycled PET fibre and its application as concrete-reinforcing fibre. Cement Concr Compos 2007;29:448-55.

[76] Modro NL, Modro N, Modro NR, Oliveira A. Avaliação de concreto de cimento Portland contendo resíduos de PET. Revista Matéria 2009;14:725-36.

[77] Albano C, Camacho N, Hernandez M, Gutierrez A. Influence of content and particle size of waste pet bottles on concrete behaviour at different $\mathrm{w} / \mathrm{c}$ ratios. Waste Manage 2009;29:2707-16.

[78] Choi Y, Moon D, Kim Y, Lachemi M. Characteristics of mortar and concrete containing fine aggregate manufactured from recycled waste polyethylene terephthalate bottles. Constr Build Mater 2009;23:2829-35.

[79] Akcaozoglu S, Atis C, Akcaozoglu SK. An investigation on the use of shredded waste PET bottles as aggregates in lightweight concrete. Waste Manage 2010;30:285-90.

[80] Frigione M. Recycling of PET bottles as fine aggregates in concrete. Waste Manage 2010.

[81] Hannawi K, Kamali-Bernard S, Prince W. Physical and mechanical properties of mortars containing PET and PC waste aggregates. Waste Management 2010;30:2312-20.

[82] Silva D, Betioli A, Gleize P, Roman H, Gomez L, Ribeiro J. Degradation of recycled PET fibers in Portland cement-based materials. Cem Concr Res 2005;35:1741-6.

[83] Marzouk O. Valorization of plastic waste: thermal conductivity of concrete formulated with PET. In: $1^{\text {st }}$ International conference on engineering for waste treatment, ISBN 2-951-1591-4-6, École de Mines d́Albi-Carmaux, France; 2005.

[84] Yesilata B, Isiker Y, Turgut P. Thermal insulation enhancement in concretes by assign waste PET and rubber pieces. Constr Build Mater 2009;23:1878-82.

[85] Benosman A, Taibi H, Mouli M, Belbachir M, Senhadji Y. Diffusion of chloride ions in polymer-mortar composites. J Appl Polym Sci 2008;110:1600-5.

[86] Won J, Jang C, Lee S, Lee S, Kim H. Long-term performance of recycled PET fibre-reinforced cement composites. Constr Build Mater 2010;24:660-5.

[87] Galvão J, Portella K, Joukoski A, Mendes R, Ferreira E. Use of waste polymers in concrete repair for dam hydraulic surfaces. Construction and Building Materials 2011;25:1049-55.

[88] Laukaitis A, Zurauskas R, Keriené J. The effect of foam polystyrene granules on cement composites properties. Cement Concr Compos 2005;27:41-7.

[89] Ismail Z, Al-Hashmi E. Use of waste plastic in concrete mixture as aggregate replacement. Waste Manage 2008;28:2041-7.

[90] Panyakapo P, Panyakapo M. Reuse of thermosetting plastic waste for lightweight concrete. Waste Manage 2008;28:1581-8.

[91] Yadav I. Laboratory investigations of the properties of the concrete containing recycled plastic aggregates. IN: Master of engineering in structural engineering. Thapar University, Patiala, India; 2008

[92] Dweik H, Ziara M, Hadidoun M. Enhancing concrete strength and therma insulation using thermoset plastic waste. Int J Polym Mater 2008;57:635-56.

[93] Mounanga P, Gbongbon W, Poullain P, Turcry P. Proportioning and characterization of lightweight concrete mixtures made with rigid polyurethane foam wastes. Cem Concr Compos 2008;30:806-14.

[94] Fraj A, Kismi M, Mounanga P. Valorization of coarse rigid polyurethane foam waste in lightweight aggregate concrete. Constr Build Mate 2010;24:1069-77.

[95] Alhozaimy A, Shannag M. Performance of concretes reinforced with recycled plastic fibres. Mag Concr Res 2009;61:293-8.

[96] Kou S, Lee G, Poon C, Lai W. Properties of lightweight aggregate concrete prepared with PVC granules derived from scraped PVC pipes. Waste Manage 2009;29:621-8.

[97] Wang Y, Backer S, Li V. An experimental study of synthetic fibre reinforced cementitious composites. J Mater Science 1987;22:4281-91.

[98] Jelidi A. Conception d'un materiau composite a matrice cimentaire reinforcee par des fibres de polyester. PhD dissertation, Inst Nat Sci Appl, Lyon, France; 1991.

[99] Houget V. Etude dês caracteristiques mecaniques et physico-chimiques de composites ciments-fibres organiques. PhD dissertation, Inst Nat Sci Appl, Lyon, France; 1992 